\title{
Comparison of fermentation of diets of variable composition and microbial populations in the rumen of sheep and Rusitec fermenters. I. Digestibility, fermentation parameters, and microbial growth ${ }^{1}$
}

\author{
M. E. Martínez, ${ }^{*} \dagger$ M. J. Ranilla, ${ }^{*} \dagger$ M. L. Tejido, ${ }^{\dagger} \dagger$ S. Ramos, ${ }^{*} \dagger$ and M. D. Carro*${ }^{*}{ }^{2}$ \\ *Departamento de Producción Animal, Universidad de León, 24007 León, Spain \\ †Instituto de Ganadería de Montaña (CSIC-ULE), Finca Marzanas s/n. 24346 Grulleros, León, Spain
}

\section{ABSTRACT}

Four ruminally and duodenally cannulated sheep and 8 Rusitec fermenters were used to determine the effects of forage to concentrate $(\mathrm{F}: \mathrm{C})$ ratio and type of forage in the diet on ruminal fermentation and microbial protein synthesis. The purpose of the study was to assess how closely fermenters can mimic the dietary differences found in vivo. The 4 experimental diets contained F:C ratios of 70:30 or 30:70 with either alfalfa hay or grass hay as the forage. Microbial growth was determined in both systems using ${ }^{15} \mathrm{~N}$ as a microbial marker. Rusitec fermenters detected differences between diets similar to those observed in sheep by changing $\mathrm{F}: \mathrm{C}$ ratio on $\mathrm{pH}$; neutral detergent fiber digestibility; total volatile fatty acid concentrations; molar proportions of acetate, propionate, butyrate, isovalerate, and caproate; and amylase activity. In contrast, Rusitec fermenters did not reproduce the dietary differences found in sheep for $\mathrm{NH}_{3}-\mathrm{N}$ and lactate concentrations, dry matter (DM) digestibility, proportions of isobutyrate and valerate, carboxymethylcellulase and xylanase activities, and microbial growth and its efficiency. Regarding the effect of the type of forage in the diet, Rusitec fermenters detected differences between diets similar to those found in sheep for most determined parameters, with the exception of $\mathrm{pH}, \mathrm{DM}$ digestibility, butyrate proportion, and carboxymethylcellulase activity. Minimum $\mathrm{pH}$ and maximal volatile fatty acid concentrations were reached at $2 \mathrm{~h}$ and at 6 to $8 \mathrm{~h}$ postfeeding in sheep and fermenters, respectively, indicating that feed fermentation was slower in fermenters compared with that in sheep. There were differences between systems in the

\footnotetext{
Received November 23, 2009.

Accepted April 25, 2010.

${ }^{1}$ Funding was provided by the Spanish Ministerio de Educación y Ciencia (project AGL2004-04755-C02-01) and the Consejería de Educación de la Junta de Castilla y León (Ref. GR158). M. E. Martinez and S. Ramos gratefully acknowledge the receipt of an F. P. U. scholarship from the Ministerio de Educacion y Ciencia of Spain (AP2005-1797 and BES-2005-6842, respectively).

${ }^{2}$ Corresponding author: mdcart@unileon.es
}

magnitude of most determined parameters. In general, fermenters showed lower lactate concentrations, neutral detergent fiber digestibility, acetate:propionate ratios, and enzymatic activities. On the contrary, fermenters showed greater $\mathrm{NH}_{3}-\mathrm{N}$ concentrations, DM digestibility, and proportions of propionate, butyrate, isovalerate, valerate, and caproate. Values of efficiency of microbial growth were greater in fermenters compared with sheep for 70:30 diets, but they were lower for 30:70 diets. Differences between fermentation in sheep and fermenters can be mainly attributed to the lack of absorption in fermenters, differences in solid retention time, and compartmentalization in the Rusitec system. In general, the Rusitec system simulated more closely the in vivo fermentation of high-forage diets compared with high-concentrate diets.

Key words: Rusitec, sheep, forage:concentrate ratio, microbial growth

\section{INTRODUCTION}

The interactions between microorganisms and the complexity of the chemical reactions that take place in the rumen make the study of ruminal function under strictly controlled conditions difficult. Moreover, ruminal studies usually require the use of cannulated animals, which comprises ethical and legal problems, besides being laborious and expensive. All these problems have led to the development of in vitro systems for simulating ruminal fermentation. Many types of artificial rumen apparatus have been described in the literature, ranging from simple continuous fermentation systems (Weller and Pilgrim, 1974) to complicated fermenters that allow precise control of $\mathrm{pH}$ and liquid and solid turnover rates (Hoover et al., 1976). Studies that have compared in vitro with in vivo fermentation patterns are rare in the literature, although recently several papers have dealt with this topic (Ziemer et al., 2000; Carro et al., 2009; Muetzel et al., 2009). To our knowledge, all previous studies have been carried out with continuous-flow fermenters (Mansfield et al., 1995; Ziemer et al., 2000; Muetzel et al., 2009) or batch 
cultures (Gizzi et al., 1998), and only 1 study has recently investigated how closely the semicontinuous-flow Rusitec system mimics ruminal fermentation (Carro et al., 2009). The Rusitec system was designed by Czerkawski and Breckenridge (1977) as a simple apparatus for maintaining a normal ruminal population under strictly controlled conditions over long periods of time, and it has been widely used in many laboratories during the past few decades.

In previous studies conducted at our laboratory (Gómez et al., 2005; Carro et al., 2009) we noticed that shifts in fermentation attributed to changes in the dietary forage to concentrate $(\mathbf{F}: \mathbf{C})$ ratio in Rusitec fermenters did not reproduce the changes usually found in vivo. Whereas the simulation of ruminal fermentation was quite satisfactory for high-forage diets, fermentation of high-concentrate diets resulted in unphysiological acetate:propionate ratios with values higher than 4.0. The Rusitec system was designed to operate at a fixed solid retention time of $48 \mathrm{~h}$ for both forages and concentrates (Czerkawski and Breckenridge, 1977), although concentrate feeds have been shown to have shorter retention times in the rumen compared with forages (Mambrini and Peyraud, 1997). In a recent study, Martínez et al. (2009) observed that increasing dilution rate from 3.78 to $5.42 \% / \mathrm{h}$ and decreasing concentrate retention time from 48 to $24 \mathrm{~h}$ in Rusitec fermenters fed a high-concentrate diet decreased acetate:propionate ratio, and hypothesized that using higher dilution rates and shorter concentrate retention time than those usually used in Rusitec experiments might improve simulation of in vivo fermentation of high-concentrate diets. However, no studies have been conducted to test this hypothesis, although experimental comparisons are necessary to validate the use of Rusitec as a reliable model for the study of ruminal fermentation of diets of different composition.

The aim of this study was to assess to what extent Rusitec fermenters can be used to characterize the effects of diet on patterns of ruminal fermentation observed in sheep. For that purpose, the effects of 4 diets differing in $\mathrm{F}$ : $\mathrm{C}$ ratio and type of forage (FOR) on ruminal parameters and microbial growth were assessed in sheep, and the results were compared with those observed in Rusitec fermenters given the same diets.

\section{MATERIALS AND METHODS}

\section{Diets}

Four total mixed diets were formulated according to a $2 \times 2$ factorial arrangement of treatments. The diets had F:C (DM basis) ratios of 70:30 (high forage; HF) or 30:70 (high concentrate; HC) with either alfalfa hay
(A) or grass hay $(\mathbf{G})$ as forage, and were designated as HFA, HFG, HCA, and HCG. Ingredients and chemical composition of diets are shown in Table 1. The alfalfa hay was a second cut harvested at $30 \%$ flowering and contained $91.3 \% \mathrm{DM}, 2.67 \% \mathrm{~N}, 46.6 \% \mathrm{NDF}$, and $33.1 \%$ ADF (DM basis). The grass hay consisted primarily of perennial ryegrass (81\%), red and white clover (11\%), and other grasses (8\%); was harvested at postflowering stage; and contained 93.3\% DM, 1.46\% N, 56.9\% NDF, and 28.6\% ADF (DM basis). The concentrate contained $91.4 \% \mathrm{DM}, 3.04 \% \mathrm{~N}, 33.5 \% \mathrm{NDF}$, and $12.5 \%$ ADF (DM basis).

\section{In Vivo Trial: Animals and Experimental Procedure}

Four Merino sheep $(58.5 \pm 3.16 \mathrm{~kg}$ of BW) fitted with permanent ruminal and T-type duodenal cannulas were used. Sheep were operated on following the procedures described by Komarek (1981) 2 mo before starting the experiments. Cannulas were inserted into the dorsal sac of the rumen and proximal duodenum (4 to $5 \mathrm{~cm}$ from the pyloric sphincter). Animals were cared for and handled in accordance with the Spanish Animal Care Regulations (Spanish Government, 2005), and the experimental protocols were approved by the León University Institutional Animal Care and Use Committee. Sheep were housed in individual pens and had continuous access to fresh water and vitamin-mineral block over the experimental period. Diets were offered to the animals twice daily (0800 and $2000 \mathrm{~h}$ ) at a daily rate of $56 \mathrm{~g}$ of $\mathrm{DM} / \mathrm{kg}$ of $\mathrm{BW}^{0.75}$ to minimize feed selection. This level of intake was estimated to meet 1.2, 1.1, 1.4, and 1.3 times the energy maintenance requirements of the experimental sheep for HFA, HFG, HCA, and HCG diets, respectively (NRC, 1985).

The experimental design was a $4 \times 4$ Latin square with 4 dietary treatments, 4 periods, and 4 sheep. Each 25-d experimental period consisted of $14 \mathrm{~d}$ of dietary adaptation and $11 \mathrm{~d}$ (d 15 to 25 ) for sample and data collection. The following schedule was employed: continuous infusions of flow and microbial markers from $\mathrm{d}$ 17 to 25 , collection of duodenal digesta from d 22 to 24 , and sampling of ruminal contents on d 25. During the sampling period, samples of feed offered and refusals were collected daily and composited. Samples were dried at $55^{\circ} \mathrm{C}$ in an oven for $48 \mathrm{~h}$ and ground using a Culatti grinder (model DFH 48, Culatti, Zurich, Switzerland) with a 1-mm screen before chemical analyses.

On d 15 of each period, about $400 \mathrm{~g}$ of ruminal contents was taken through the cannula of each sheep and strained through 4 layers of cheesecloth. Five milliliters was immediately frozen at $-80^{\circ} \mathrm{C}$ for determination of carboxymethylcellulose, xylanase, and amylase activities. The remaining rumen content was used for bac- 
Table 1. Ingredients and chemical composition of the 4 experimental diets with forage:concentrate ratios of 70:30 (HF) or 30:70 (HC) and alfalfa hay $(\mathrm{A})$ or grass hay $(\mathrm{G})$ as forage

\begin{tabular}{|c|c|c|c|c|}
\hline Item & HFA & HFG & HFA & HFG \\
\hline \multicolumn{5}{|l|}{ Ingredient, $\%$ of $\mathrm{DM}$} \\
\hline Alfalfa hay & 70 & - & 30 & - \\
\hline Grass hay & - & 70 & - & 30 \\
\hline Barley & 6.4 & 6.4 & 15.2 & 15.2 \\
\hline Gluten feed & 6.1 & 6.1 & 14.5 & 14.5 \\
\hline Wheat middlings & 5.7 & 5.7 & 13.7 & 13.7 \\
\hline Soybean meal & 4.1 & 4.1 & 9.7 & 9.7 \\
\hline Palmkern meal & 3.8 & 3.8 & 9.0 & 9.0 \\
\hline Wheat & 1.5 & 1.5 & 3.5 & 3.5 \\
\hline Corn & 1.5 & 1.5 & 3.5 & 3.5 \\
\hline Vitamin-mineral premix ${ }^{1}$ & 1.0 & 1.0 & 1.0 & 1.0 \\
\hline \multicolumn{5}{|l|}{ Chemical composition } \\
\hline DM, \% & 92.7 & 92.5 & 92.5 & 92.4 \\
\hline $\mathrm{OM}, \%$ of DM & 91.3 & 92.7 & 91.3 & 91.9 \\
\hline $\mathrm{N}, \%$ of DM & 2.69 & 1.94 & 2.83 & 2.56 \\
\hline${ }^{15} \mathrm{~N}, \%$ atoms & 0.3670 & 0.3673 & 0.3674 & 0.3675 \\
\hline NDF, $\%$ of DM & 42.6 & 49.9 & 37.4 & 40.1 \\
\hline $\mathrm{ADF}, \%$ of $\mathrm{DM}$ & 26.9 & 23.8 & 18.7 & 17.4 \\
\hline $\mathrm{ME},{ }^{2} \mathrm{Mcal} / \mathrm{kg}$ of DM & 2.12 & 2.00 & 2.45 & 2.39 \\
\hline
\end{tabular}

teria cultivation, protozoa counting, and isolation of ruminal bacteria for analyzing bacterial diversity, and the results are reported in a companion paper (Martínez et al., 2010).

On d 16, ruminal content samples (about $50 \mathrm{~g}$ ) were taken through the cannula of each sheep at $0,2,4,6$, $8,10,12,14,16,18,20$, and $22 \mathrm{~h}$ after the morning feeding. Ruminal content was strained through 4 layers of cheesecloth and the $\mathrm{pH}$ of the fluid was immediately measured. Five milliliters of fluid was added to $5 \mathrm{~mL}$ of deproteinizing solution (100 g of metaphosphoric acid and $0.6 \mathrm{~g}$ of crotonic acid/L) for VFA analysis, $2 \mathrm{~mL}$ was added to $2 \mathrm{~mL}$ of $0.5 \mathrm{M} \mathrm{HCl}$ for $\mathrm{NH}_{3}-\mathrm{N}$ determination, and $5 \mathrm{~mL}$ was frozen at $-20^{\circ} \mathrm{C}$ for total lactate analyses.

Chromium-mordanted fiber and Co-EDTA were used as solid and fluid phase markers, respectively, to assess the duodenal flow of digesta, and ${ }^{15} \mathrm{~N}$ was used as a microbial marker. Chromium-mordanted fiber was prepared from the total mixed diets given to the animals according to Udén et al. (1980). From d 17 to 25, $15 \mathrm{~g}$ of Cr-mordanted fiber was administered daily via the ruminal cannula in 4 equal portions at 0800,1400 , 2000, and $0200 \mathrm{~h}$. The Co-EDTA (Udén et al., 1980) and ${ }^{15} \mathrm{NH}_{4} \mathrm{Cl}$ (10\% atom excess; Tracer SA, Madrid, Spain) were dissolved in distilled water and infused into the rumen $(250 \mathrm{~mL} / \mathrm{d})$ at constant daily rate of $60 \mathrm{mg}$ of Co and $30 \mathrm{mg}$ of ${ }^{15} \mathrm{~N}$ by means of a peristaltic pump (Gilson Minipuls Evolution, Gilson Inc., Middleton, WI).

On d 22, 23, and 24, duodenal digesta samples were collected at 6 -h intervals. The sampling time was ad- justed ahead $2 \mathrm{~h}$ daily to obtain a sample representative of daily duodenal flow. Samples were pooled by sheep and stored at $-20^{\circ} \mathrm{C}$. Duodenal samples were thawed at $4^{\circ} \mathrm{C}$ and homogenized, and half of each sample was centrifuged $(1,000 \times g, 5 \mathrm{~min})$ to obtain particulate matter (Faichney, 1975). Samples of both whole duodenal digesta and particulate matter were freeze dried and analyzed for ash, NAN, NDF, ADF, and ${ }^{15} \mathrm{~N}$.

On d 25, about $200 \mathrm{~g}$ of rumen contents were withdrawn from each sheep at 0,4 , and $8 \mathrm{~h}$ after the morning feeding. Rumen contents were squeezed through 4 layers of cheesecloth and the solid digesta was combined with an equal volume of saline solution $(0.9 \%$ $\mathrm{NaCl})$ at $38^{\circ} \mathrm{C}$, mixed gently, and squeezed again to remove residual liquid-associated bacteria (LAB). The filtrate obtained at each sampling time was kept at $4^{\circ} \mathrm{C}$, pooled per sheep, and used to isolate LAB by differential centrifugation (Ranilla and Carro, 2003). The solid digesta was treated with saline solution $(0.9 \% \mathrm{NaCl})$ containing $0.1 \%$ methylcellulose as described by Ranilla and Carro (2003) before isolation of solid-associated bacteria (SAB). Bacterial pellets (LAB and SAB) were weighed, lyophilized, ground to a fine powder with a mortar and pestle, and analyzed for $\mathrm{N}$ and ${ }^{15} \mathrm{~N}$ enrichment.

\section{In Vitro Trial: Apparatus, Experimental Procedure, and Sampling}

Two identical 16-d incubation runs were carried out using 8 Rusitec fermenters (Czerkawski and Breckenridge, 1977). Fermenters had an effective volume of 
$600 \mathrm{~mL}$, and the general incubation procedure was as described by Martínez et al. (2009). Treatments were assigned randomly so that in each run 2 fermenters received each of the diets. The inoculum was obtained from 8 ruminally fistulated sheep $(59.2 \pm 3.51 \mathrm{~kg}$ of BW). Two sheep received each of the 4 experimental diets for $14 \mathrm{~d}$ before starting the in vitro trial. On the first day of each incubation run, each fermenter was inoculated with $250 \mathrm{~mL}$ of strained rumen fluid, 200 $\mathrm{mL}$ of artificial saliva, and $80 \mathrm{~g}$ of solid rumen content supplied into a nylon bag. Ruminal contents from each sheep were collected immediately before the morning feeding, mixed by diet, strained through 2 layers of cheesecloth, and transferred to the corresponding fermenters within $30 \mathrm{~min}$ of collection.

The flow through fermenters was maintained by continuous infusion of artificial saliva $(\mathrm{pH}=8.4 ; 9.8$ $\mathrm{g}$ of $\mathrm{NaHCO}_{3}, 3.72 \mathrm{~g}$ of $\mathrm{Na}_{2} \mathrm{HPO}_{4}, 0.47 \mathrm{~g}$ of $\mathrm{NaCl}$, $0.57 \mathrm{~g}$ of KCl, $0.053 \mathrm{~g}$ of $\mathrm{CaCl}_{2} \cdot 2 \mathrm{H}_{2} \mathrm{O}$, and $0.128 \mathrm{~g}$ of $\left.\mathrm{MgCl}_{2} \cdot 6 \mathrm{H}_{2} \mathrm{O} / \mathrm{L} ; \mathrm{McDougall}, 1948\right)$ at a rate of $740 \mathrm{~mL} / \mathrm{d}$ (dilution rate of $5.14 \% / \mathrm{h}$ ). Each fermenter received daily $30 \mathrm{~g}$ of $\mathrm{DM}$ of the corresponding diet (Table 1 ). Hay was chopped (approximately at $0.5-\mathrm{cm}$ pieces), and the concentrate was ground through a $3-\mathrm{mm}$ sieve. Forage and concentrate were fed once daily $(0800 \mathrm{~h})$ into separate nylon bags $(100 \mu \mathrm{m}$ pore; $8 \times 15 \mathrm{~cm})$, which were incubated for 48 and $24 \mathrm{~h}$, respectively. Dilution rate and solids retention time were chosen to resemble values previously observed in vivo in sheep (Ranilla et al., 1998; Carro et al., 2000; Valdés et al., 2000). Each fermenter was flushed daily with $2 \mathrm{~L}$ of $\mathrm{CO}_{2}$ before and after feeding to remove gases produced during the fermentation and the air introduced in the fermenter during feeding, respectively.

On d 10, a dose of $3.5 \mathrm{mg}$ of ${ }^{15} \mathrm{~N}$ (98\% enriched ${ }^{15} \mathrm{NH}_{4} \mathrm{Cl}$; Tracer SA) was added to each fermenter to instantaneously label the ammonia N pool. From d 10 to 15 , a solution of ${ }^{15} \mathrm{NH}_{4} \mathrm{Cl}$ was added to the artificial saliva at a rate of $4.0 \mathrm{mg}$ of ${ }^{15} \mathrm{~N} / \mathrm{g}$ of dietary $\mathrm{N}$. On d $10,11,12$, and $13, \mathrm{pH}$ of the fluid of each fermenter was determined immediately before feeding and the following samples were collected. Liquid effluent was collected daily in flasks containing a solution of $\mathrm{H}_{2} \mathrm{SO}_{4}$ (20\%; vol/vol) to maintain $\mathrm{pH}$ below 2 . One milliliter of effluent was added to $1 \mathrm{~mL}$ of deproteinizing solution (10\% of metaphosphoric acid and $0.06 \%$ crotonic acid; wt/vol) for VFA determination, and $5 \mathrm{~mL}$ of effluent was stored at $-20^{\circ} \mathrm{C}$ for ammonia $\mathrm{N}$ and total lactate determinations. Two nylon bags (1 with forage and 1 with concentrate) from each fermenter were collected daily, washed twice with $40 \mathrm{~mL}$ of fermenter liquid, and then washed in the cold rinse cycle $(20 \mathrm{~min})$ of a washing machine. The DM apparent disappearance was calculated from loss in weight after oven drying at $60^{\circ} \mathrm{C}$ for $48 \mathrm{~h}$, and the residues were analyzed for NDF and $\mathrm{ADF}$.

On d 14 and 15 a water solution saturated with $\mathrm{HgCl}_{2}$ ( $5 \mathrm{~mL}$ ) was added (replacing the $\mathrm{H}_{2} \mathrm{SO}_{4}$ solution that could cause bacterial lysis) to the overflow containers, which were held in an ice water bath to impede microbial growth. Approximately $500 \mathrm{~mL}$ of effluent was used for isolation of LAB. The contents of nylon bags removed on d 15 and 16 were used to determine the growth of SAB. About $20 \%$ of solid content from each nylon bag was frozen and lyophilized for determination of DM, NAN, and ${ }^{15} \mathrm{~N}$ enrichment. The SAB pellets were isolated after treating the remaining solid content with a saline solution of $0.1 \%$ methylcellulose as described above.

On d 15, about $3 \mathrm{~mL}$ of fermenter fluid was taken at $0,2,4,6,8,10$, and $12 \mathrm{~h}$ after feeding, the $\mathrm{pH}$ was immediately measured, and $1 \mathrm{~mL}$ of fluid was added to $1 \mathrm{~mL}$ of deproteinizing solution for VFA analysis. In addition, $3 \mathrm{~mL}$ of fermenter fluid was taken at $0 \mathrm{~h}$ and immediately frozen at $-80^{\circ} \mathrm{C}$ for determination of carboxymethylcellulase, xylanase, and amylase activities. Fermenter fluid was also sampled at $0 \mathrm{~h}$ for bacteria cultivation, protozoa counting, and isolation of ruminal bacteria for analyzing bacterial diversity; the results are reported in a companion paper (Martínez et al., 2010).

\section{Analytical Procedures}

Dry matter (method 934.01), ash (method 942.05), and N (method 984.13) were determined according to AOAC (1999). Analyses of NDF and ADF were carried out according to Van Soest et al. (1991) using an Ankom ${ }^{220}$ Fiber Analyzer unit (Ankom Technology Corp., Fairport, NY). Sodium sulfite and heat-stable amylase were used in analysis of NDF and ADF, and they were expressed inclusive of residual ash.

Analyses of VFA, ammonia N, and lactate have been described by Carro and Miller (1999). Marker (Co, Cr) concentrations in both whole and solid duodenal samples were analyzed by atomic emission spectrophotometry (AES-ICP, Perkin Elmer 2000 DV, Uberlingen, Germany) after wet digestion according to Williams et al. (1962). Wavelengths for $\mathrm{Cr}$ and $\mathrm{Co}$ were 268 and $228 \mathrm{~nm}$, respectively, and values were corrected for concentrations of $\mathrm{Cr}$ and Co determined in each sheep before infusion of markers. Procedures for NAN and ${ }^{15} \mathrm{~N}$ analysis in feeds, digesta, and bacterial isolates have been reported by Carro and Miller (1999), and analyses of ${ }^{15} \mathrm{~N}$ enrichment were performed by isotope ratio mass spectrometry (VG Prism II, Middlewich, UK) connected in series to a Dumas-style N analyzer (model 1108, Carlo Erba Instruments, Milan, Italy). 
For determination of enzymatic activities in ruminal fluid samples, samples were defrosted and cells were lysed using a Mini-Beadbeater (BioSpec Products Inc., Bartlesville, OK) to release intracellular enzymes. The treatment consisted of three 60 -s pulses at $4^{\circ} \mathrm{C}$ using 0.1-mm glass beads. Unbroken cell material was removed by centrifugation $\left(10,000 \times g, 10 \mathrm{~min}, 4^{\circ} \mathrm{C}\right)$, and the supernatant $(200 \mu \mathrm{L})$ was used for analyses. Carboxymethylcellulase, xylanase, and amylase activities were determined following the procedures described by Giraldo et al. (2008) using as substrates carboxymethylcellulose, oat spelt xylan, and soluble starch, respectively. Enzymatic activities were expressed as nanomoles of glucose or xylose released from the corresponding substrates by $1 \mathrm{~mL}$ of ruminal fluid in $1 \mathrm{~min}$ at $39^{\circ} \mathrm{C}$ and $\mathrm{pH} 6.5$.

\section{Calculations and Statistical Analyses}

Duodenal flow in sheep was calculated from the concentrations of $\mathrm{Cr}$ and $\mathrm{Co}$ in duodenal digesta phases using the dual-phase maker method of Faichney (1975). Samples were mathematically reconstituted to create a representative sample from the concentrations of each analyzed nutrient in each of the duodenal phases (Faichney, 1975). The flow of microbial $\mathrm{N}$ at the duodenum was calculated using ${ }^{15} \mathrm{~N}$ as a microbial marker and the mean value between ${ }^{15} \mathrm{~N}$ enrichment in $\mathrm{LAB}$ and $\mathrm{SAB}$ as ${ }^{15} \mathrm{~N}$ enrichment in reference bacteria (calculated from the relative proportions of each bacterial fraction in the total amount of pellet isolated) as follows:

microbial NAN flow $(\mathrm{g} / \mathrm{d})=$ DM digesta flow $(\mathrm{g} / \mathrm{d})$

$\times \mathrm{NAN}$ in digesta $(\mathrm{g} / \mathrm{g}$ of $\mathrm{DM}) \times\left({ }^{15} \mathrm{~N}\right.$ atom $\%$ excess

in digesta $/{ }^{15} \mathrm{~N}$ atom $\%$ excess in bacterial reference).

In fermenters, the proportion of digesta NAN (liquid or solid) of microbial origin was estimated by dividing the ${ }^{15} \mathrm{~N}$ enrichment (atoms $\%$ in excess) of the NAN portion of digesta by the enrichment of the corresponding bacterial pellets (LAB or SAB). Daily microbial N production of $\mathrm{LAB}$ and $\mathrm{SAB}$ was estimated by multiplying total NAN production in the corresponding digesta (liquid or solid) by the proportion attributed to the microbes. Total daily microbial production was calculated as the sum of the flows of $\mathrm{LAB}$ and SAB. The natural ${ }^{15} \mathrm{~N}$ content in diets before ${ }^{15} \mathrm{~N}$ infusion was used for background correction in vivo and in vitro.

The efficiency of microbial growth was expressed as milligrams of microbial $\mathrm{N}$ per gram of $\mathrm{OM}$ apparently fermented. The amount of OM apparently fermented in the rumen of sheep was calculated as the difference between the $\mathrm{OM}$ intake and $\mathrm{OM}$ duodenal flow. The amount of OM apparently fermented in the fermenters was estimated from VFA production using the equation proposed by Blanchart et al. (1989).

In vivo and in vitro data were analyzed separately to asses the effects of dietary treatments on each fermentation system. Data from in vivo trial were analyzed according to a $4 \times 4$ Latin square model using the MIXED procedure of SAS (SAS Institute Inc., Cary, NC) according to the following model:

$$
\mathrm{Y}_{\mathrm{ijkl}}=\mu+\mathrm{c}_{\mathrm{i}}+\mathrm{P}_{\mathrm{j}}+\mathrm{FC}_{\mathrm{k}}+\mathrm{F}_{\mathrm{l}}+\mathrm{FCF}_{\mathrm{kl}}+\mathrm{e}_{\mathrm{ijk} \mathrm{k}},
$$

where $\mathrm{Y}_{\mathrm{ijkl}}=$ the dependent variable; $\mu=$ the overall mean; $\mathrm{c}=$ the random effect of sheep ( $\mathrm{i}=1$ to 4$) ; \mathrm{P}=$ the fixed effect of period $(\mathrm{j}=1$ to 4$) ; \mathrm{FC}=$ the fixed effect of $\mathrm{F}: \mathrm{C}(\mathrm{k}=1$ to 2$) ; \mathrm{F}=$ the fixed effect of FOR (1 $=1$ to 2$) ; \mathrm{FCF}=$ the interaction of $\mathrm{F}: \mathrm{C}$ and $\mathrm{FOR}$; and $\mathrm{e}=$ the residual error. In the analysis of in vitro data the random effect of fermenter was $\mathrm{i}=1$ to 8 and the fixed effect of period was $\mathrm{j}=1$ to 2 . When a significant $(P \leq 0.05) \mathrm{F}: \mathrm{C} \times \mathrm{FOR}$ interaction was detected, differences among means were tested using Tukey's multiple comparison test.

\section{RESULTS AND DISCUSSION}

As pointed out by Czerkawski and Breckenridge (1977), it is difficult to judge how closely an in vitro technique simulates the in vivo rumen and what the most appropriate measurements are. Clearly, no direct comparisons can be made when the outputs are expressed as daily amounts of products because absolute amounts of input and outflow from animals and fermenters usually differ in magnitude; therefore, only data with similar units (i.e., proportions and concentrations) should be statistically compared (Mansfield et al., 1995). Fermenters are frequently used to analyze differences between different dietary treatments, and from a practical point of view it would be interesting to assess whether they can detect the same differences observed in vivo. Therefore, the main objective of the present study was to assess the ability of Rusitec fermenters to detect the same changes in ruminal fermentation and microbial growth promoted by feeding diets of contrasting quality to sheep. To achieve this objective, the effects of F:C ratio and FOR on ruminal parameters and microbial growth were analyzed independently within each fermentation system.

Rusitec fermenters were run under the conditions that are usually used in our laboratory. Although ruminal fluid from a single animal has been used to inoculate fermenters in some studies (Ziemer et al., 2000; Hess et al., 2003), in our laboratory at least 2 different animals 
Table 2. Ruminal $\mathrm{pH}, \mathrm{NH}_{3}-\mathrm{N}$, and lactate concentrations and apparent diet digestibility in the rumen of sheep and Rusitec fermenters receiving diets differing in forage:concentrate ratio $(\mathrm{F}: \mathrm{C})$ and type of forage (FOR)

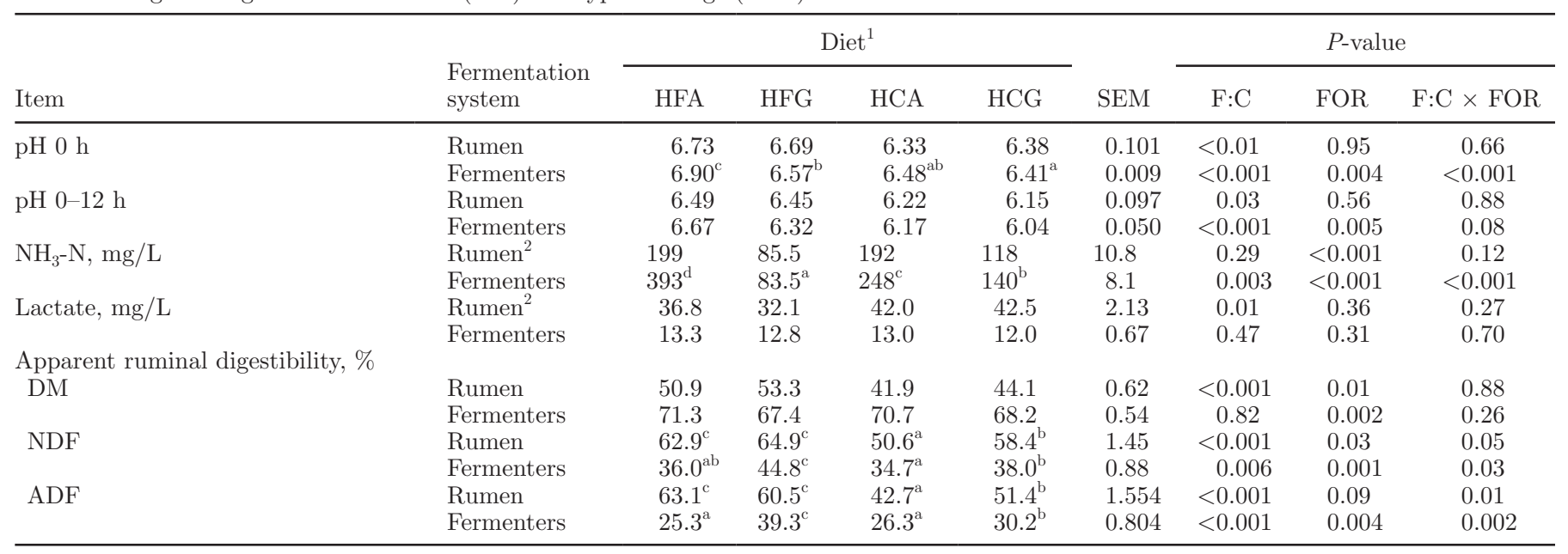

${ }^{\mathrm{a}-\mathrm{c}}$ Means within a row with different superscripts differ $(P<0.05$; Tukey's test). Superscripts are shown only when a significant $(P \leq 0.05) \mathrm{F}$ : C $\times$ FOR interaction was detected.

${ }^{1}$ HFA: 70:30 alfalfa hay:concentrate; HFG: 70:30 grass hay:concentrate; HCA: 30:70 alfalfa hay:concentrate; HCG: 30:70 grass hay:concentrate. DM basis.

${ }^{2}$ Values are means across sampling times of $0,2,4,6,8,10,12,14,16,18,20$, and $22 \mathrm{~h}$ after a.m. feeding.

per treatment are regularly used as donors to obtain a more representative microbial population. Recently, Muetzel et al. (2009) observed that fermenters inoculated with ruminal fluid from 2 different cows showed a completely different evolution of protozoa population over the incubation period: whereas protozoa from one cow were broadly maintained in the fermenters, protozoa from the other cow decreased close to the detection limit within $12 \mathrm{~d}$; this illustrates the importance of using mixed inocula from more than a single animal.

The approach followed in this study differs from that used in other comparisons in vivo versus in vitro. Mansfield et al. (1995), Ziemer et al. (2000), and Muetzel et al. (2009) directly compared fermentation variables determined in fermenters with those measured in the donor animals. Because our aim was to assess to what extent Rusitec fermenters could detect differences between diets similar to those found in sheep, the in vivo trial was conducted first with 4 sheep, and for the in vitro trial 4 additional sheep were used as ruminal fluid donors. This was done to have 2 donor sheep per dietary treatment. Although 4 sheep were used in the in vivo trial, we decided to use 8 fermenters in the in vitro trial because in previous experiments a significant effect of fermenter on fermentation parameters was never detected (Gómez et al., 2005; Carro et al., 2009; Martínez et al., 2009) and therefore a Latin square design was considered not necessary.

The effects of F:C ratio and FOR on ruminal fermentation in both fermentation systems are shown in Tables 2, 3, 4, and 5. In general, $P$-values of ANOVA were greater in vivo than in Rusitec fermenters, which was attributed to the greater variability found for most measured variables in sheep (values of coefficient of variation ranging from 2.1 to $25 \%$ ) compared with fermenters (values from 1.2 to $17 \%$ ). Ruminal $\mathrm{pH}$ before feeding and mean values of $\mathrm{pH}$ over the $12 \mathrm{~h}$ postfeeding were greater for the $\mathrm{HF}$ diets compared with $\mathrm{HC}$ diets in sheep and fermenters $(P<0.001$ to 0.03 ; Table 2 ). Whereas FOR in the diet did not affect $\mathrm{pH}$ values measured either immediately before feeding $(P=0.95)$ or over the 12 -h postfeeding period in sheep $(P=0.56)$, both variables were greater in fermenters fed A diets compared with those fed $\mathrm{G}$ diets $(P=0.004$ and 0.005 , respectively). Alfalfa hay has been shown to have a greater buffer capacity than grass hay (Fadel, 1992), and this may explain the greater $\mathrm{pH}$ values observed in A-fed fermenters. In sheep, FOR in the diet influences rumination activity, digestion rate, and saliva production, factors that can further affect ruminal $\mathrm{pH}$ and cannot be simulated in fermenters.

As shown in Figure 1, the postfeeding evolution of $\mathrm{pH}$ in fermenters differed from that observed in sheep. Ruminal $\mathrm{pH}$ in sheep decreased markedly $2 \mathrm{~h}$ postfeeding for all diets and gradually increased afterward, whereas in Rusitec fermenters $\mathrm{pH}$ decreased progressively after feeding and reached minimum values at 6 to $8 \mathrm{~h}$ after feed supply. In both systems, the decrease in $\mathrm{pH}$ was more pronounced for the $\mathrm{HC}$ diets than for HF diets: whereas ruminal $\mathrm{pH}$ did not decrease below 6.0 for $\mathrm{HF}$ diets in either sheep or fermenters, minimum $\mathrm{pH}$ values of 5.8 were observed in both systems for $\mathrm{HC}$ diets. 
Table 3. Ruminal VFA concentrations, molar proportions of VFA, and acetate:propionate ratio in the rumen of sheep and Rusitec fermenters receiving diets differing in forage:concentrate ratio $(\mathrm{F}: \mathrm{C})$ and type of forage $(\mathrm{FOR})$

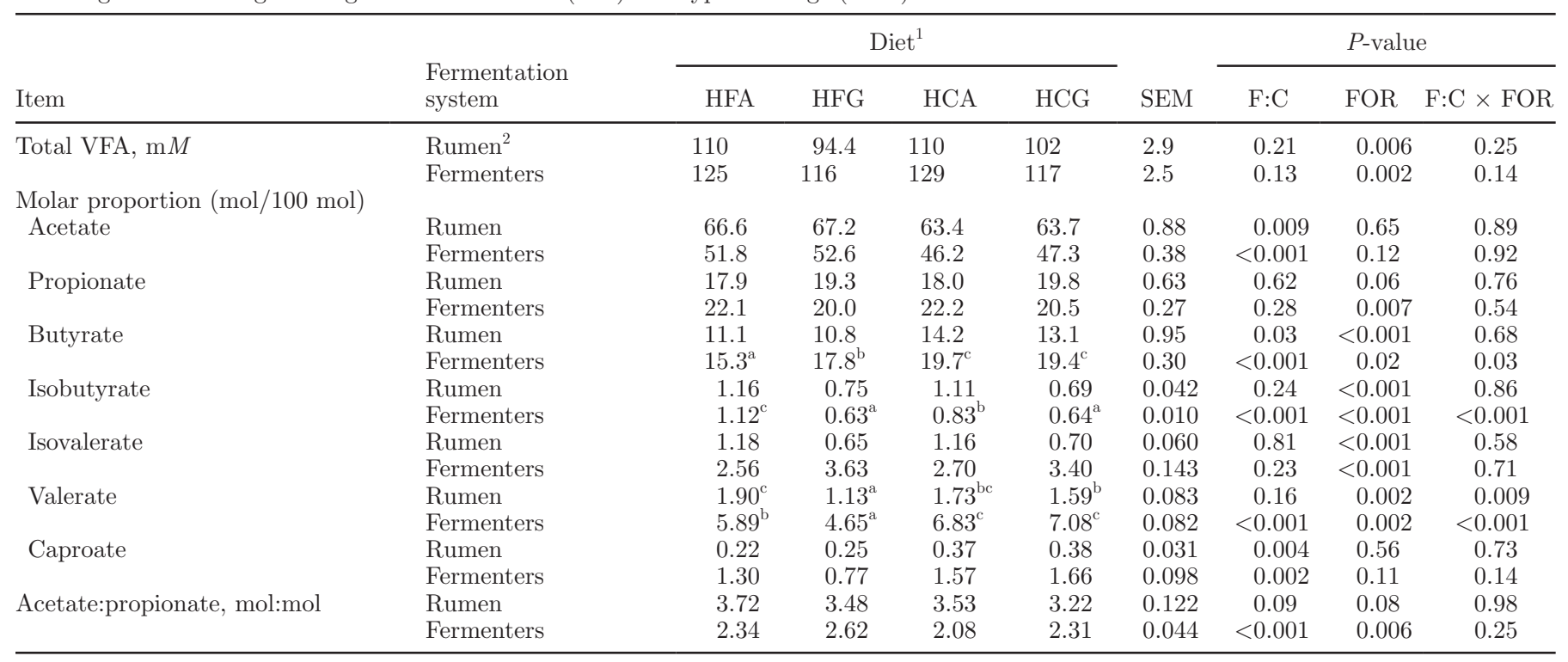

${ }^{\mathrm{a}-\mathrm{c}}$ Means within a row with different superscripts differ $(P<0.05$; Tukey's test). Superscripts are shown only when a significant $(P \leq 0.05) \mathrm{F}: \mathrm{C}$ $\times$ FOR interaction was detected.

${ }^{1}$ HFA: 70:30 alfalfa hay:concentrate; HFG: 70:30 grass hay:concentrate; HCA: 30:70 alfalfa hay:concentrate; HCG: 30:70 grass hay:concentrate. DM basis.

${ }^{2}$ Values are means across sampling times of $0,2,4,6,8,10,12,14,16,18,20$, and $22 \mathrm{~h}$ after a.m. feeding.

The postfeeding evolution of $\mathrm{pH}$ would indicate that feed fermentation was slower in fermenters compared with sheep, and this is also indicated by the evolution of total VFA concentrations in ruminal fluid (Figure 2 ); total VFA concentrations in sheep increased shortly after feeding, reaching maximum values $2 \mathrm{~h}$ after feed intake, whereas in VFA concentrations fermenters increased gradually to maximum values at $6 \mathrm{~h}$ after feed supply. These differences between sheep and fermenters might be related to the way of operation of Rusitec fermenters. Each day, 2 bags containing undigested feed are removed, drained, and washed twice with fermenter fluid and washes are returned to fermenter. When the undigested feed enclosed in the nylon bags is washed, a proportion of microbial matter can be removed (Czerkawski and Breckenridge, 1979), but considerable microbial mass still remains attached to feed particles and is removed from the fermenter. In this study, the proportion of microbial $\mathrm{N}$ in the undigested feed residues was $62,73,54$, and $55 \%$ of the total daily microbial $\mathrm{N}$ output for diets HFA, HFG, HCA, and HCG, respectively (values not shown). In the ruminant, feed entering the rumen is readily (within 5 to $15 \mathrm{~min}$ of feed ingestion) colonized by the microorganisms resi-

Table 4. Enzymatic activities in ruminal fluid from sheep and Rusitec fermenters receiving diets differing in forage:concentrate ratio (F:C) and type of forage (FOR)

\begin{tabular}{|c|c|c|c|c|c|c|c|c|c|}
\hline Item $^{1}$ & $\begin{array}{l}\text { Fermentation } \\
\text { system }\end{array}$ & \multicolumn{4}{|c|}{ Diet $^{2}$} & SEM & \multicolumn{3}{|c|}{$P$-value } \\
\hline Carboxymethylcellulase & Rumen & 0.94 & 0.85 & 1.46 & 1.09 & 0.061 & $<0.001$ & 0.009 & 0.07 \\
\hline \multirow[t]{2}{*}{ Xylanase } & Rumen & 8.10 & 7.42 & 1.07 & 1.09 & 0.640 & 0.003 & 0.68 & 0.55 \\
\hline & Fermenters & 1.09 & 1.11 & 1.16 & 1.09 & 0.054 & 0.69 & 0.62 & 0.40 \\
\hline Amylase & Rumen & 1.72 & 1.55 & 4.99 & 5.54 & 0.337 & $<0.001$ & 0.58 & 0.32 \\
\hline
\end{tabular}

${ }^{1}$ Carboxymethylcellulase and amylase activities are expressed as micromoles of glucose released from carboxymethylcellulose and soluble starch by $1 \mathrm{~mL}$ of ruminal fluid in $1 \mathrm{~min}$ at $39^{\circ} \mathrm{C}$ and $\mathrm{pH}$ 6.5. Xylanase activity is expressed as micromoles of xylose liberated from oat spelt xylan by $1 \mathrm{~mL}$ of ruminal fluid in $1 \mathrm{~min}$ at $39^{\circ} \mathrm{C}$ and $\mathrm{pH} 6.5$.

${ }^{2}$ HFA: 70:30 alfalfa hay:concentrate; HFG: 70:30 grass hay:concentrate; HCA: 30:70 alfalfa hay:concentrate; HCG: 30:70 grass hay:concentrate. DM basis. 
Table 5. Nitrogen content and ${ }^{15} \mathrm{~N}$ enrichment of liquid-associated bacteria (LAB) and solid-associated (SAB) bacteria, proportion of bacterial $\mathrm{N}$ derived from $\mathrm{NH}_{3}-\mathrm{N}$, bacterial colonization of solid digesta, microbial N flow, $\mathrm{N}$ degradability, and efficiency of microbial synthesis (EMS) in sheep and Rusitec fermenters receiving diets differing in forage:concentrate ratio $(\mathrm{F}: \mathrm{C})$ and type of forage $(\mathrm{FOR})$

\begin{tabular}{|c|c|c|c|c|c|c|c|c|c|}
\hline \multirow[b]{2}{*}{ Item } & \multirow{2}{*}{$\begin{array}{l}\text { Fermentation } \\
\text { system }\end{array}$} & \multicolumn{4}{|c|}{$\operatorname{Diet}^{1}$} & \multirow[b]{2}{*}{ SEM } & \multicolumn{3}{|c|}{$P$-value } \\
\hline & & HFA & HFG & $\mathrm{HCA}$ & HCG & & $\mathrm{F}: \mathrm{C}$ & FOR & $\mathrm{F}: \mathrm{C} \times \mathrm{FOR}$ \\
\hline \multirow[t]{2}{*}{$\mathrm{N}$ content of $\mathrm{LAB}, \mathrm{mg} / \mathrm{g}$ of $\mathrm{DM}$} & Rumen & 64.7 & 69.2 & 63.7 & 66.2 & 1.62 & 0.26 & 0.07 & 0.57 \\
\hline & Fermenters & 64.1 & 64.2 & 73.1 & 70.7 & 0.87 & $<0.001$ & 0.26 & 0.20 \\
\hline \multirow[t]{2}{*}{$\mathrm{N}$ content of $\mathrm{SAB}, \mathrm{mg} / \mathrm{g}$ of $\mathrm{DM}$} & Rumen & 66.4 & 66.7 & 65.0 & 67.2 & 1.18 & 0.70 & 0.33 & 0.44 \\
\hline & Fermenters & 59.7 & 60.7 & 63.6 & 61.6 & 1.08 & 0.08 & 0.70 & 0.23 \\
\hline \multirow{3}{*}{$\begin{array}{l}{ }^{15} \mathrm{~N} \text { enrichment, atoms } \% \text { excess } \\
\mathrm{LAB}\end{array}$} & & & & & & & & & \\
\hline & Rumen & $0.0725^{\mathrm{b}}$ & $0.1372^{\mathrm{d}}$ & $0.0604^{\mathrm{a}}$ & $0.0871^{\mathrm{c}}$ & 0.00332 & $<0.001$ & $<0.001$ & $<0.001$ \\
\hline & Fermenters & $0.4170^{\mathrm{a}}$ & $0.8255^{\mathrm{d}}$ & $0.5300^{\mathrm{b}}$ & $0.7541^{\mathrm{c}}$ & 0.00873 & 0.06 & $<0.001$ & $<0.001$ \\
\hline \multirow[t]{2}{*}{$\mathrm{SAB}$} & Rumen & $0.0609^{\mathrm{a}}$ & $0.1175^{\mathrm{c}}$ & $0.0581^{\mathrm{a}}$ & $0.0808^{\mathrm{b}}$ & 0.00424 & 0.004 & $<0.001$ & 0.007 \\
\hline & Fermenters & $0.1459^{\mathrm{a}}$ & $0.3674^{\mathrm{c}}$ & $0.2352^{\mathrm{b}}$ & $0.3557^{\mathrm{c}}$ & 0.00583 & 0.001 & $<0.001$ & $<0.001$ \\
\hline \multirow[t]{2}{*}{ LAB- $\mathrm{N}$ derived from $\mathrm{NH}_{3}-\mathrm{N}, \%$} & Rumen & 37.8 & 51.8 & 35.4 & 44.1 & 1.18 & 0.005 & $<0.001$ & 0.06 \\
\hline & Fermenters & 53.6 & 53.6 & 52.5 & 52.4 & 1.03 & 0.31 & 0.93 & 0.97 \\
\hline \multirow[t]{2}{*}{$\mathrm{SAB}-\mathrm{N}$ derived from $\mathrm{NH}_{3}-\mathrm{N}, \%$} & Rumen & $33.8^{\mathrm{a}}$ & $46.8^{\mathrm{c}}$ & $35.4^{\mathrm{a}}$ & $40.6^{\mathrm{b}}$ & 1.42 & 0.15 & $<0.001$ & 0.03 \\
\hline & Fermenters & $18.8^{\mathrm{a}}$ & $23.9^{\mathrm{b}}$ & $23.3^{\mathrm{b}}$ & $24.7^{\mathrm{b}}$ & 0.61 & 0.008 & 0.003 & 0.03 \\
\hline \multirow{4}{*}{$\begin{array}{l}\text { Bacterial colonization of solid digesta, } \\
\% \text { of digesta DM } \\
\text { Microbial N flow, g/d }\end{array}$} & Rumen & 21.2 & 19.8 & 25.9 & 25.3 & 1.07 & 0.003 & 0.38 & 0.72 \\
\hline & Fermenters & 22.9 & 21.3 & 16.0 & 15.3 & 0.96 & 0.001 & 0.28 & 0.65 \\
\hline & Rumen & 13.7 & 9.8 & 17.0 & 15.5 & 0.55 & $<0.001$ & 0.003 & 0.07 \\
\hline & Fermenters & $0.300^{c}$ & $0.256^{\mathrm{b}}$ & $0.234^{\mathrm{a}}$ & $0.224^{\mathrm{a}}$ & 0.0064 & $<0.001$ & 0.009 & 0.05 \\
\hline \multirow{2}{*}{$\mathrm{N}$ degradability, $\%$} & Rumen & 80.7 & 76.3 & 77.0 & 76.1 & 2.57 & 0.49 & 0.35 & 0.53 \\
\hline & Fermenters & 83.8 & 85.9 & 74.9 & 73.9 & 0.90 & $<0.001$ & 0.73 & 0.15 \\
\hline \multirow{2}{*}{$\begin{array}{l}\text { EMS, } g \text { of microbial } \mathrm{N} / \mathrm{kg} \text { of } \mathrm{OM} \\
\text { apparently digested in the rumen }\end{array}$} & Rumen & 22.6 & 19.2 & 33.3 & 31.4 & 0.80 & $<0.001$ & 0.02 & 0.39 \\
\hline & Fermenters & 31.9 & 28.9 & 25.9 & 26.7 & 0.78 & 0.003 & 0.02 & 0.10 \\
\hline
\end{tabular}

O ${ }^{\mathrm{a}-\mathrm{d}}$ Means within a row with different superscripts differ $(P<0.05$; Tukey's test). Superscripts are shown only when a significant $(P \leq 0.05) \mathrm{F}$ : $\times$ FOR interaction was detected.

$\underset{\sim}{0} \quad{ }^{1}$ HFA: 70:30 alfalfa hay:concentrate; HFG: 70:30 grass hay:concentrate; HCA: 30:70 alfalfa hay:concentrate; HCG: 30:70 grass hay:concentrate. DM basis. 
dent in ruminal fluid and plateaus or reverses either as microbial density on the particle exceeds attachment sites or potentially digestible substrates are exhausted (Cheng and McAllister, 1997). In the Rusitec system, the microbes enclosed in the nylon bags remaining from the previous day in the fermenters and those in the liq- uid phase have to reach the new feed supplied every day and colonize the feed particles, and this could explain the delayed increase in VFA concentrations observed in fermenters compared with sheep. In addition, Rusitec fermenters are opened to introduce new nylon bags with feed; this operation exposes the ruminal micro-
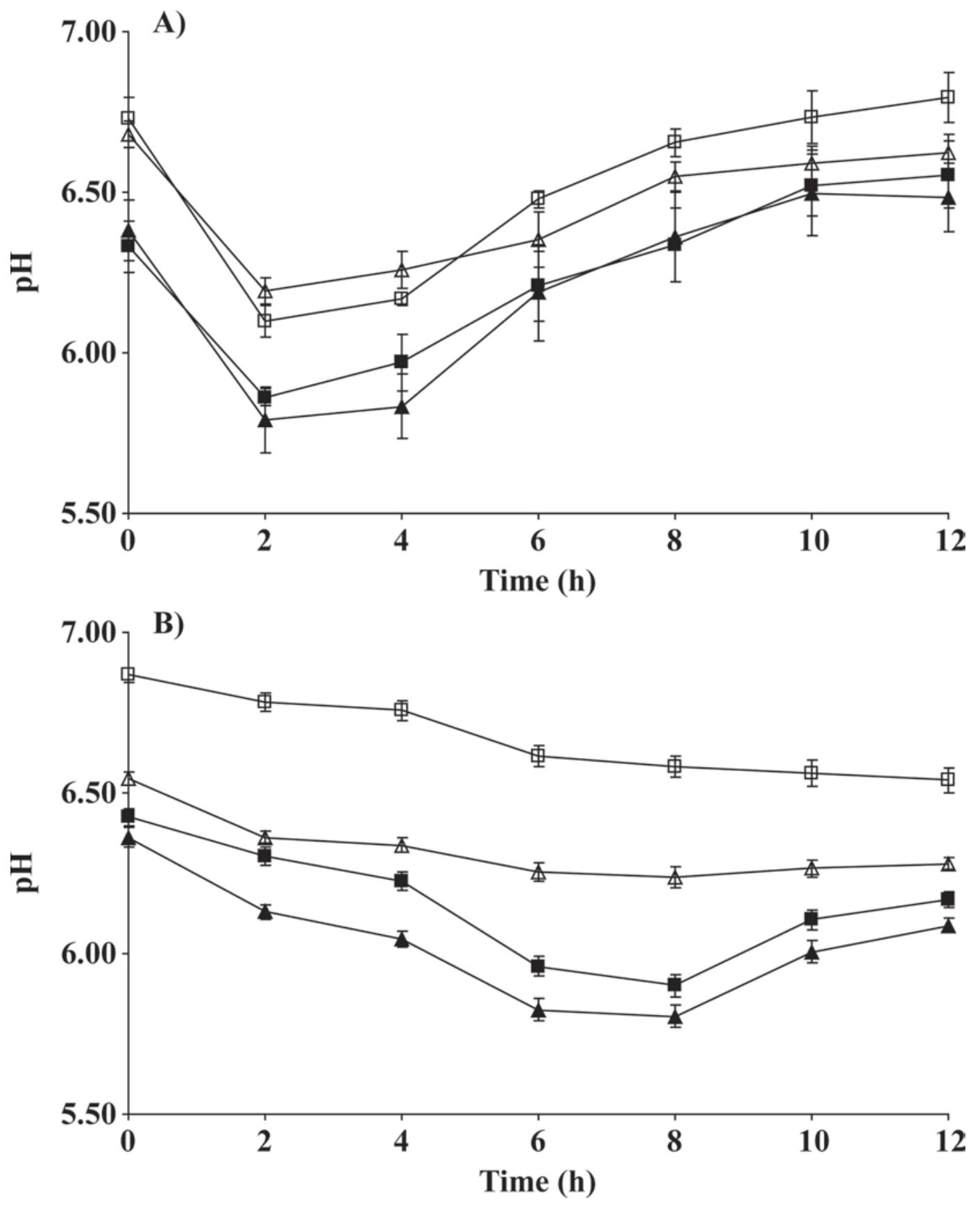

Figure 1. pH in A) the rumen of sheep and B) Rusitec fermenters fed diets with forage:concentrate ratios of 70:30 (open symbols) or 30:70 (shaded symbols) and alfalfa hay $(\square, \boldsymbol{\square})$ or grass hay $(\Delta, \boldsymbol{\Delta})$ as forage. Sheep were fed at 0 and $12 \mathrm{~h}$ and fermenters were fed once daily at 0 h. Error bars are SEM. 
organisms to oxygen and creates a substantial stress situation for the strict anaerobic microorganisms (Gizzi et al., 1998).

The F:C ratio in the diet did not affect $\mathrm{NH}_{3}-\mathrm{N}$ concentrations in sheep $(P=0.29)$, but significant effects were found in Rusitec, with HC-fed fermenters showing lower values than $\mathrm{HF}$-fed fermenters $(P=0.003$; Table
$2)$. The lower $(P<0.001) \mathrm{NH}_{3}-\mathrm{N}$ levels observed in both systems for $\mathrm{G}$ diets compared with sheep and fermenters fed A diets may have been attributable to the lower $\mathrm{N}$ input (Table 1). Whereas $\mathrm{NH}_{3}-\mathrm{N}$ levels observed in Rusitec fermenters fed the HFA diet were atypical of what is usually observed in the rumen (Mackie et al., 1978; Carro et al., 2000), $\mathrm{NH}_{3}-\mathrm{N}$ concentrations in fer-
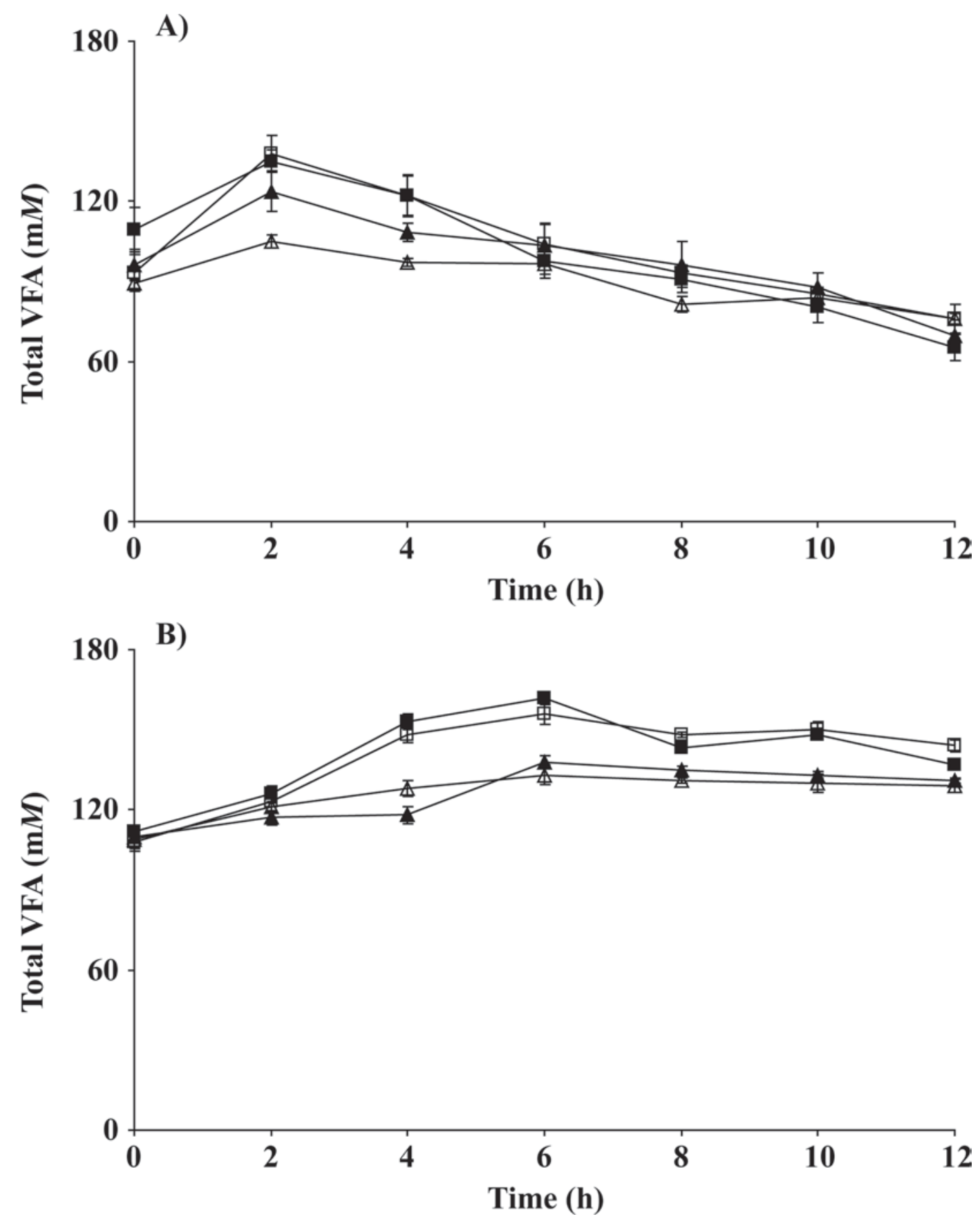

Figure 2. Total VFA concentrations in A) sheep and B) fermenters fed diets with forage:concentrate ratios of 70:30 (open symbols) or 30:70 (shaded symbols) and alfalfa hay $(\square, \boldsymbol{\square})$ or grass hay $(\Delta, \mathbf{\Delta})$ as forage. Sheep were fed at 0 and $12 \mathrm{~h}$ and fermenters were fed once daily at 0 h. Error bars are SEM. 
menters fed the other 3 diets were in the range of those found in vivo. Ruminal lactate concentrations were greater $(P=0.01)$ in sheep fed HC diets compared with those fed HF diets, but no differences $(P=0.47)$ attributed to $\mathrm{F}: \mathrm{C}$ ratio were observed in fermenters. Lactate concentrations in sheep rumen were lower than those reported by others in sheep in latent acidosis fed HC diets (Mackie et al., 1978; Brossard et al., 2003). It is probable that the moderate level of feeding and the fibrous nature of the concentrate used in the present experiment (containing 33.5\% NDF and only $32 \%$ cereal grains; Table 1) prevented the rapid decrease in $\mathrm{pH}$ that is characteristic of animals given larger amounts of cereal grains. In addition, the fact that animals received mixed diets could have reduced the negative effects on $\mathrm{pH}$ usually observed by the fermentation of $\mathrm{HC}$ diets because mixed diets tend to minimize the daily variations in rumen $\mathrm{pH}$ (Carro et al., 2000). The FOR did not affect lactate concentrations in either sheep $(P=$ $0.36)$ or fermenters $(P=0.31)$. Lactate concentrations were 3.0 times lower in fermenters than in sheep rumen (mean value for all diets), which may suggest either lower lactate production or greater lactate utilization in the fermenters compared with sheep. The low lactate concentrations observed in Rusitec are in accordance with the values previously reported by others (Czerkawski and Breckenridge, 1979; Alves de Olivera et al., 1997). Alves de Olivera et al. (1997) reported that an efficient lactate-fermenting population was achieved rapidly in Rusitec fermenters and hypothesized that the low levels of lactate, associated with the observed increase in butyrate and caproate in their study, may be explained by the presence of Megasphaera elsdenii, the major ruminal lactolytic bacteria. In our study, molar proportions of butyrate and caproate were 1.5 and 4.4 times greater, respectively, than in sheep (mean values for all diets; Table 3), which is in agreement with the observations of Alves de Olivera et al. (1997).

As shown in Table 2, sheep fed HF diets showed greater $(P<0.001)$ ruminal digestibility of DM than those fed HC diets, but no differences $(P=0.82)$ were observed in fermenters. In contrast, both systems detected similar differences in ruminal digestibility of NDF and ADF, values being greater for $\mathrm{HF}$ diets compared with $\mathrm{HC}$ diets $(P<0.001$ and 0.006 for sheep and fermenters, respectively, for NDF digestibility; $P<0.001$ for both systems for ADF digestibility). The lower ruminal fiber digestibility observed for HC diets could be attributed to the lower $\mathrm{pH}$ values found for these diets because cellulolytic bacteria are known to be very $\mathrm{pH}$ sensitive and their growth and activity start to decline significantly at $\mathrm{pH}$ values below 6.0 (Russell and Wilson, 1996). Although $\mathrm{pH}$ did not decrease below 6.0 at any sampling time for $\mathrm{HF}$ diets in both systems, values for $\mathrm{HC}$ diets were below 6.0 at 2 and $4 \mathrm{~h}$ after feeding in sheep and at 6 and $8 \mathrm{~h}$ after feeding in fermenters (Figure 1). The NDF digestibility was 1.1 times greater for $\mathrm{G}$ diets than for A diets both in vivo $(P=0.03)$ and in vitro $(P$ $=0.001)$, which is consistent with the idea that grass fiber is more digestible than that of legumes. Similar results were observed for ADF digestibility, which was 1.1 times greater for $\mathrm{G}$ diets than for A diets in vivo $(P=0.09)$ and 1.3 times greater in vitro $(P=0.004)$. In agreement with the results of Mansfield et al. (1995) comparing ruminal digestibility of 4 diets in cows with that in dual-flow continuous-culture fermenters, values of NDF and ADF digestibility in our study were about 1.5 and 1.8 times greater, respectively, in sheep compared with fermenters.

Supplementation of forage diets with readily fermentable carbohydrates usually results in increased total ruminal VFA concentrations (Pérez et al., 1996), but a lack of response to different $\mathrm{F}: \mathrm{C}$ ratios in the diet has also been observed (Carro et al., 2000). In our study, total VFA concentrations were not affected by $\mathrm{F}: \mathrm{C}$ ratio in either sheep $(P=0.21)$ or fermenters $(P=0.13)$. The lack of effect of $\mathrm{F}: \mathrm{C}$ ratio on VFA concentrations in fermenters is in accordance with the absence of differences among diets in DM digestibility, but in sheep lower DM digestibilities were observed for $\mathrm{HC}$ diets compared with HF diets. Whereas there is no absorption in fermenters, and thus VFA concentrations should be directly related to the amount of DM digested, VFA concentrations do not necessarily reflect VFA production in sheep because of absorption through the rumen wall and passage with the fluid to the omasum. Total VFA concentrations were about 1.1 times greater for A diets than for $\mathrm{G}$ diets in both sheep $(P=0.006)$ and fermenters $(P=0.002)$.

The effect of $\mathrm{F}: \mathrm{C}$ ratio on the VFA profile is not clear in the literature. In some studies (Mackie et al., 1978; Carro et al., 2000) decreasing F:C ratio increased the proportions of propionate and butyrate at the expense of acetate, but in others it increased butyrate at the expense of acetate and propionate (Brossard et al., 2003). In this study, decreasing $\mathrm{F}: \mathrm{C}$ ratio resulted in decreased acetate $(P=0.009$ and $<0.001$ for sheep and fermenters, respectively) and butyrate $(P=0.03$ and $<0.001)$ proportions, increased of caproate proportions $(P=0.004$ and 0.002$)$, and unchanged propionate $(P$ $=0.62$ and 0.28$)$ and isovalerate $(P=0.81$ and 0.23$)$ proportions (Table 3 ). In contrast, differences between systems in detecting the effects of $\mathrm{F}: \mathrm{C}$ ratio were detected in the proportions of isobutyrate and valerate: $\mathrm{HC}$ fermenters showed lower isobutyrate $(P<0.001)$ and greater $(P<0.001)$ valerate proportions compared with HF fermenters, whereas no differences between sheep fed $\mathrm{HC}$ and HF diets were observed $(P=0.24$ and 
0.16 , respectively). In agreement with previous studies (Mackie et al., 1978; Carro et al., 2000), decreasing F:C ratio in the diet tended $(P=0.09)$ to decrease acetate:propionate ratio in sheep and decreased it in fermenters $(P<0.001)$.

Although the results indicate that Rusitec fermenters detected differences between $\mathrm{HF}$ and $\mathrm{HC}$ diets in the proportions of the main VFA similar to those observed in sheep, values of VFA proportions differed between systems. Acetate, propionate, butyrate, isobutyrate, isovalerate, valerate, and caproate proportions in fermenters were $0.79,1.14,1.51,0.90,3.88,3.61$, and 4.49 times those observed in sheep for HF diets, respectively, and $0.74,1.13,1.43,0.84,3.59,4.20$, and 4.31 times those observed in sheep for $\mathrm{HC}$ diets, respectively. The lower acetate and greater butyrate and minor VFA proportions found in fermenters compared with sheep confirm previous observations made in our laboratory with Rusitec fermenters (Carro et al., 2009). Results obtained with dual-flow or single-flow continuousculture fermenters are contradictory. Mansfield et al. (1995) found greater butyrate, valerate, and branchedchain VFA proportions in dual-flow continuous culture fermenters than in the rumen of cows fed 4 diets differing in their content in NFC and ruminally degradable protein, but observed no significant differences in acetate proportions. Ziemer et al. (2000) observed lower proportions of acetate, isobutyrate, and isovalerate and greater valerate proportions in dual-flow continuous culture fermenters than in the rumen of the donor cow. On the contrary, Muetzel et al. (2009) found no differences in the proportions of VFA in single-flow continuousculture fermenters compared with those found in the rumen of cows. The different operating conditions in the fermenters and diets used in the studies cited previously might contribute to explaining these contradictory results. In our study, there were positive relationships between the VFA proportions found in sheep and those in fermenters $(\mathrm{n}=4)$ for acetate $(\mathrm{r}=0.996 ; P=0.004)$ and propionate $(\mathrm{r}=0.917 ; P=0.08)$, but no relationship $(P=0.31)$ was observed for butyrate.

Both systems detected similar differences attributable to FOR, with the exception of butyrate proportion (Table 3). The FOR did not influence the proportion of acetate $(P=0.65$ and 0.12 in sheep and fermenters, respectively) and caproate $(P=0.56$ and 0.11$)$, but proportions of propionate, isobutyrate, isovalerate, and valerate were greater $(P<0.001$ to 0.05$)$ for $\mathrm{A}$ diets than for $\mathrm{G}$ diets. The greater concentrations of isobutyrate, isovalerate, and valerate observed with A diets might be attributable to a more extensive protein degradation compared with $\mathrm{G}$ diets because these VFA are produced by the fermentation of branched-chain AA. Mean values of $\mathrm{N}$ degraded were 24.6 and $19.2 \mathrm{~g} / \mathrm{d}$ for
A and $\mathrm{G}$ diets, respectively, in sheep and 656 and 534 $\mathrm{mg} / \mathrm{d}$, respectively, in fermenters (data not shown).

In contrast with other studies in which fibrolytic activities in the rumen were either not affected or decreased by increasing the proportion of concentrate in the diet (Hristov et al., 2001; Martin et al., 2001), carboxymethylcellulase and xylanase activities in sheep ruminal fluid were greater $(P<0.001)$ for $\mathrm{HC}$ diets compared with HF diets (Table 4). Our results could be partly explained by the high ruminal $\mathrm{pH}$ values, which did not decrease at any sampling time below 5.8 in sheep fed HC diets (Figure 1), but it reached lower values in the previously cited studies. In contrast, no differences between $\mathrm{HF}$ and $\mathrm{HC}$ diets were observed in Rusitec fermenters $(P=0.27$ and 0.69 for carboxymethylcellulase and xylanase, respectively) despite the considerably lower interindividual variability observed for enzymatic activities in fermenters compared with sheep. This is in contrast to the greater NDF digestibility observed for HF diets (Table 2), but it should be taken into account that fibrolytic activity in the liquid phase of the rumen is very low compared with the activities in the solid digesta (Cheng and McAllister, 1997), and differences between liquid and solid phases may be more pronounced in the Rusitec system because of its greater compartmentalization compared with in vivo.

In agreement with others (Martin and MichaletDoreau, 1995; Hristov et al., 2001), increasing F:C ratio resulted in increased $(P<0.001)$ amylase activities in ruminal fluid in sheep and fermenters. There were no effects of FOR on any enzymatic activity, with the exception of carboxymethylcellulase activity, which was greater $(P=0.009)$ in sheep fed A diets than in those fed G diets. Muetzel et al. (2009) reported that cellulase activity in single-flow continuous-culture fermenters remained similar to the values observed in the rumen of donor cows, but xylanase activity increased 2.8 times over the incubation period in fermenters. All the enzymatic activities determined in our study were numerically lower in fermenters than in vivo, but the magnitude of the differences was influenced by the diet. Values of amylase activity in sheep were 6.5 times greater than in fermenters for HF diets but only 1.5 times greater for $\mathrm{HC}$ diets. Xylanase activity was similar in sheep and fermenters for $\mathrm{HC}$ diets, but sheep showed values 7.1 times greater than fermenters for $\mathrm{HF}$ diets.

One of the key measurements of an in vitro system is microbial growth, because of the difficulties in determining microbial protein synthesis in vivo associated with the use of cannulated animals and digesta flow markers. However, a microbial marker is still necessary to differentiate microbial $\mathrm{N}$ from undegraded feed $\mathrm{N}$. 
In this study ${ }^{15} \mathrm{~N}$ was chosen as a microbial marker because previous work has shown that it is more accurate and precise than other markers (Carro and Miller, 2002; Ipharraguerre et al., 2007). As shown in Table 5, ${ }^{15} \mathrm{~N}$ enrichment in LAB isolated from sheep was greater $(P<0.001)$ for HF diets compared with HC diets, but differences attributable to $\mathrm{F}: \mathrm{C}$ ratio in the diet did not reach the significance level in fermenters $(P=0.06)$. In both systems, ${ }^{15} \mathrm{~N}$ enrichment of LAB and SAB was greater for $\mathrm{G}$ diets compared with $\mathrm{A}$ diets, possibly because of the greater ${ }^{15} \mathrm{~N}$ enrichment of the $\mathrm{NH}_{3}-\mathrm{N}$ fraction observed for $\mathrm{G}$ diets (results not shown).

The proportion of LAB- $\mathrm{N}$ derived from $\mathrm{NH}_{3}-\mathrm{N}$ fraction in sheep was greater for HF diets than for HC diets and for $\mathrm{G}$ diets than for $\mathrm{A}$ diets, but no differences attributable to $\mathrm{F}$ :C ratio $(P=0.31)$ or FOR $(P=0.93)$ were observed in fermenters. In both systems, $\mathrm{G}$ diets promoted a greater capture of ${ }^{15} \mathrm{NH}_{3}-\mathrm{N}$ by SAB compared with $\mathrm{A}$ diets $(P<0.001$ and 0.003 for sheep and fermenters, respectively), although ${ }^{15} \mathrm{NH}_{3} \mathrm{~N}$ capture was 1.7 times greater in sheep compared with fermenters (mean value for all diets).

A lower enrichment of SAB compared with LAB has been often reported in vivo (Ipharraguerre et al., 2007) and in Rusitec fermenters (Carro and Miller, 2002; Gómez et al., 2005). In paired $t$-tests within each fermentation system (in vivo or in vitro), ${ }^{15} \mathrm{~N}$ enrichment was lower $(P<0.001)$ in $\mathrm{SAB}$ than in $\mathrm{LAB}$ (mean values of 0.0793 and 0.0893 atoms \% in excess, respectively, in sheep, and 0.2761 and 0.6317 atoms \% in excess, respectively, in fermenters). Whereas LAB are located in free suspension or loosely associated with fibers, SAB are located bound to plant surfaces, where the actual ammonia concentration may be lower than in rumen fluid and could fluctuate widely. As a consequence of the differences in ${ }^{15} \mathrm{~N}$ enrichment between bacterial fractions, the proportion of bacterial $\mathrm{N}$ derived from $\mathrm{NH}_{3}-\mathrm{N}$ was greater in $\mathrm{LAB}$ than in $\mathrm{SAB}$ in sheep ( 42.3 vs. $39.2 \% ; P=0.007)$ and in fermenters (53.0 vs. $22.7 \% ; P<0.001$ ). The observed differences in ${ }^{15} \mathrm{~N}$-specific enrichment of SAB and LAB emphasize the necessity of a differential study of these 2 bacterial populations to obtain a reliable estimate of total microbial protein synthesis in vivo and in vitro.

There were no differences between diets in $\mathrm{N}$ degradability in sheep $(P=0.49$ and 0.35 for F:C and FOR, respectively), but HF diets had greater $(P<0.001) \mathrm{N}$ degradability compared with $\mathrm{HC}$ diets in fermenters. Microbial $\mathrm{N}$ flow in sheep was greater $(P<0.001)$ for HC diets compared with HF diets, whereas HF diets promoted greater $(P<0.001)$ microbial growth than $\mathrm{HC}$ diets in fermenters. The greater microbial $\mathrm{N}$ flow observed in sheep fed HC diets could be partially explained by the greater intakes of energy and N (Table
1) because the yield of microbial biomass is related to the amount of available energy and N. The lower microbial growth observed in fermenters fed $\mathrm{HC}$ diets is difficult to explain, but it might be related to the different retention times of forage and concentrate in the Rusitec system. As shown in Table 5, bacterial colonization of solid digesta was greater for HF diets than for $\mathrm{HC}$ diets (22.1 vs. $15.7 \%$ ), which may be attributable to the longer retention time of forage compared with concentrate (48 vs. $24 \mathrm{~h}$ ). As a consequence, SAB growth was greater in fermenters fed HF diets than in those fed HC diets (186 and $125 \mathrm{mg} / \mathrm{d}$, respectively; data not shown). The greater energy and $\mathrm{N}$ content in A diets compared with $\mathrm{G}$ diets is consistent with the greater microbial growth observed in vivo $(P=0.003)$ and in vitro $(P=0.009)$ for A diets.

The values of efficiency of microbial synthesis, expressed as grams of microbial $\mathrm{N}$ per kilogram of $\mathrm{OM}$ apparently digested in the rumen, were in the range of those found in the literature in sheep fed diets differing in F:C ratio (Pérez et al., 1996; Archimède et al., 1997) and were lower $(P<0.001)$ for $\mathrm{HF}$ diets than for $\mathrm{HC}$ diets. In contrast, efficiency of microbial growth was lower $(P=0.003)$ in fermenters fed HC diets compared with those receiving HF diets because of the greater microbial growth in HC-fed fermenters and the lack of differences between $\mathrm{HF}$ and $\mathrm{HC}$ diets in the amount of OM fermented (9.12 vs. $8.71 \mathrm{~g} / \mathrm{d}$, respectively; values not shown). In sheep, the diet HFG had the lowest $(P<0.05)$ efficiency of microbial growth, probably attributable to a limitation of microbial growth caused by the low energy and $\mathrm{N}$ content in the diet (Table 1), because $\mathrm{N}$ degradability was similar to that for $\mathrm{HC}$ diets (Table 5).

\section{CONCLUSIONS}

There were differences between sheep and fermenters in the magnitude of most parameters, and only $\mathrm{pH}$ and concentrations of total VFA showed similar values in both systems. As assessed by postfeeding changes in $\mathrm{pH}$ and total VFA concentrations, fermenters had a slower feed fermentation compared with sheep. When differences among diets attributed to the type of forage in the diet were analyzed, interpretation of results in vivo and in vitro was similar for most of the measured parameters. On the contrary, there were differences between in vivo and fermenters in the interpretation of the effects of F:C ratio in about half of the measured parameters, including the efficiency of microbial growth, and therefore interpretation of results was changed. Some of the discrepancies could be attributed to the lack of absorption in fermenters, differences in solids retention time, and the way of operation of the 
Rusitec fermenters. Studies identifying the changes in microbial populations through the incubation period in the Rusitec system are needed to understand the observed differences.

\section{REFERENCES}

Alves de Oliveira, L. A., C. Jean-Blain, S. Komisarczuk-Bony, A. Durix, and C. Durier. 1997. Microbial thiamin metabolism in the rumen simulating fermenter (RUSITEC): The effect of acidogenic conditions, a high sulfur level and added thiamine. Br. J. Nutr. 78:599-613.

Archimède, H., D. Sauvant, and P. Schmidely. 1997. Quantitative review of ruminal and total tract digestion of mixed diet organic matter and carbohydrates. Reprod. Nutr. Dev. 7:173-189.

AOAC. 1999. Official Methods of Analysis. 16th ed. 5th rev. AOAC International, Gaithersburg, MD.

Blanchart, G., M. Durant, J. L. Barry, M. Bouiller-Oudot, and J. P. Jouany. 1989. Intérêts et limites des fermenteurs à flux semicontinu de type Rusitec dans l'étude des fermentations du rumen [Advantages and limits of the semi-continuous artificial rumen (Rusitec) for the study of rumen fermentation]. Ann. Zootech. 38:285-314.

Brossard, L., C. Martin, and B. Michalet-Doreau. 2003. Ruminal fermentative parameters and blood acid-basic balance changes during the onset and recovery of induced latent acidosis in sheep. Anim. Res. 52:513-530.

Carro, M. D., and E. L. Miller. 1999. Effect of supplementing a fibre basal diet with different nitrogen forms on ruminal fermentation and microbial growth in an in vitro semicontinuous culture system (RUSITEC). Br. J. Nutr. 82:149-157.

Carro, M. D., and E. L. Miller. 2002. Comparison of microbial markers $\left({ }^{15} \mathrm{~N}\right.$ and purine bases) and bacterial isolates for the determination of rumen microbial protein synthesis. Anim. Sci. 75:315-321.

Carro, M. D., M. J. Ranilla, A. I. Martin-Garcia, and E. MolinaAlcaide. 2009. Comparison of microbial fermentation of highand low-forage diets in Rusitec, single-flow continuous-culture fermenters and sheep rumen. Animal 3:527-534.

Carro, M. D., C. Valdés, M. J. Ranilla, and J. S. González. 2000. Effect of forage to concentrate ratio in the diet on ruminal fermentation and digesta flow kinetics in sheep. Anim. Sci. 70:127-134.

Cheng, K. J., and T. A. McAllister. 1997. Compartmentation in the rumen. Pages 492-522 in The Rumen Microbial Ecosystem. P. N. Hobson and C. S. Stewart, ed. Chapman and Hall, London, UK.

Czerkawski, J. W., and G. Breckenridge. 1977. Design and development of a long-term rumen simulation technique (Rusitec). Br. J. Nutr. 38:371-384.

Czerkawski, J. W., and G. Breckenridge. 1979. Experiments with the long-term rumen simulation technique (Rusitec); Response to supplementation of basal rations. Br. J. Nutr. 42:217-228.

Fadel, J. G. 1992. In vitro buffering capacity changes of seven commodities under controlled moisture and heating conditions. J. Dairy Sci. 75:1287-1295.

Faichney, G. J. 1975. The use of markers to partition digestion within the gastro-intestinal tract of ruminants. Pages 277-291 in Digestion and Metabolism in the Ruminant. A. C. I. Warner and I. W. McDonald, ed. University of New England Publishing Unit, Armidale NSW, Australia.

Giraldo, L. A., M. L. Tejido, M. J. Ranilla, S. Ramos, and M. D. Carro. 2008. Influence of direct-fed fibrolytic enzymes on diet digestibility and ruminal activity in sheep fed a grass hay-based diet. J. Anim. Sci. 86:1617-1623.

Gizzi, G., R. Zanchi, and F. Sciaraffia. 1998. Comparison of microbiological and fermentation parameters obtained with an improved rumen in vitro technique with those obtained in vivo. Anim. Feed Sci. Technol. 73:291-305.

Gómez, J. A., M. L. Tejido, and M. D. Carro. 2005. Mixed rumen microorganisms growth and rumen fermentation of two diets in RUSITEC fermenters: Influence of disodium malate supplementation. Br. J. Nutr. 93:479-484.

Hess, H. D., L. M. Monsalve, C. E. Lascano, T. E. Carulla Díaz, and M. Kreuzer. 2003. Supplementation of a tropical grass diet with forage legumes and Sapindus saponaria fruits: Effects on in vitro ruminal nitrogen turnover and methanogenesis. Aust. J. Agric. Res. 54:703-713.

Hoover, W. H., B. A. Crooker, and C. J. Sniffen. 1976. Effects of differential solid-liquid removal rates on protozoa numbers in continuous cultures of rumen contents. J. Anim. Sci. 43:528534

Hristov, A. N., M. Ivan, L. M. Rode, and T. A. McAllister. 2001. Fermentation characteristics and ruminal ciliate protozoal populations in cattle fed medium- or high-concentrate barleybased diets. J. Anim. Sci. 79:515-524.

Ipharraguerre, I. R., S. M. Reynal, M. Lineiro, G. A. Broderick, and J. H. Clark. 2007. A comparison of sampling sites, digesta and microbial markers, and microbial references for assessing the postruminal supply of nutrients in dairy cows. J. Dairy Sci. 90:1904-1919.

Komarek, R. J. 1981. Intestinal cannulation of cattle and sheep with a T-shaped cannula designed for total digesta collection without externalizing flow. J. Anim. Sci. 53:796-802.

Mackie, R. I., F. M. C. Gilchrist, A. M. Roberts, P. E. Hannah, and H. M. Schwartz. 1978. Microbiological and chemical changes in the rumen during the stepwise adaptation of sheep to high concentrate diets. J. Agric. Sci. 90:241-254.

Mambrini, M., and J. L. Peyraud. 1997. Retention time of feed particles and liquids in the stomachs and intestines of dairy cows. Direct measurement and calculations based on faecal collection. Reprod. Nutr. Dev. 37:427-442.

Mansfield, H. R., M. I. Endres, and M. D. Stern. 1995. Comparison of microbial fermentation in the rumen of dairy cows and dual flow continuous culture. Anim. Feed Sci. Technol. 55:47-66.

Martin, C., and B. Michalet-Doreau. 1995. Variations in mass and enzyme activity of rumen microorganisms: Effect of barley and buffer supplements. J. Sci. Food Agric. 67:407-413.

Martin, C., L. Millet, G. Fonty, and B. Michalet-Doreau. 2001. Cereal supplementation modified the fibrolytic activity but not the structure of the cellulolytic bacterial community associated with rumen solid digesta. Reprod. Nutr. Dev. 41:413-424.

Martínez, M. E., M. J. Ranilla, S. Ramos, M. L. Tejido, and M. D. Carro. 2009. Effects of dilution rate and retention time of concentrate on efficiency of microbial growth, methane production, and ruminal fermentation in Rusitec fermenters. J. Dairy Sci. 92:3930-3938.

Martínez, M. E., M. J. Ranilla, M. L. Tejido, C. Saro, and M. D. Carro. 2010. Comparison of fermentation of diets of variable composition and microbial populations and in the rumen of sheep and Rusitec fermenters. II. Protozoa population and diversity of bacterial communities. J. Dairy Sci. 93:3699-3712.

McDougall, E. I. 1948. Studies on ruminant saliva. I. The composition and output of sheep's saliva. Biochem. J. 43:99-109.

Muetzel, S., P. Lawrence, E. M. Hoffmann, and K. Becker. 2009. Evaluation of a stratified continuous rumen incubation system. Anim. Feed Sci. Technol. 151:32-43.

NRC. 1985. Nutrient Requirement of Sheep. 6th ed. Natl. Acad. Press, Washington, DC.

Pérez, J. F., J. Balcells, J. A. Guada, and C. Castrillo. 1996. Determination of rumen microbial-nitrogen production in sheep: A comparison of urinary purine excretion with methods using ${ }^{15} \mathrm{~N}$ and purine bases as markers of microbial-nitrogen entering the duodenum. Br. J. Nutr. 75:699-709.

Ranilla, M. J., and M. D. Carro. 2003. Diet and procedures used to detach particulate-associated microbes from ruminal digesta influence chemical composition of microbes and estimation of microbial growth in Rusitec fermenters. J. Anim. Sci. 81:537544.

Ranilla, M. J., S. López, F. J. Giráldez, C. Valdés, and M. D. Carro. 1998. Comparative digestibility and digesta flow kinetics in two breeds of sheep. Anim. Sci. 66:389-396. 
Russell, J. B., and D. B. Wilson. 1996. Why are ruminal cellulolytic bacteria unable to digest cellulose at low $\mathrm{pH}$ ? J. Dairy Sci. 79:1503-1509.

Spanish Government. 2005. Royal Decree 1201/2005 for the protection of animals used for experimental and other scientific purposes of October 10th, BOE 252. Pages 34367-34274.

Udén, P., P. E. Colucci, and P. J. Van Soest. 1980. Investigation of chromium, cerium and cobalt as markers in digesta. Rates of passage studies. J. Sci. Food Agric. 31:625-632.

Valdés, C., M. D. Carro, M. J. Ranilla, and J. S. González. 2000 Effect of forage to concentrate ratio in complete diets fed to sheep on voluntary feed intake and some digestive parameters. Anim. Sci. 70:119-126.
Van Soest, P. J., J. B. Robertson, and B. A. Lewis. 1991. Methods for dietary fiber, neutral detergent fiber, and nonstarch polysaccharides in relation to animal nutrition. J. Dairy Sci. 74:3583-3597.

Weller, R. A., and A. F. Pilgrim. 1974. Passage of protozoa and volatile fatty acids from the rumen of the sheep and from a continuous in vitro fermentation system. Br. J. Nutr. 32:341-351.

Williams, C. H. D., D. J. David, and O. Iismaa. 1962. The determination of chromic oxide in faeces samples by atomic absorption spectrophotometry. J. Agric. Sci. 59:381-385.

Ziemer, C. J., R. Sharp, M. D. Stern, M. A. Cotta, T. R. Whitehead, and D. A. Stahl. 2000. Comparison of microbial populations in model and natural rumens using $16 \mathrm{~S}$ ribosomal RNA-targeted probes. Environ. Microbiol. 1:632-643. 